\title{
Design and implementation of multilevel non-isolated DC-DC converter for variable DC voltage source
}

\author{
Ali Ahmed Adam Ismail, A. Elnady \\ Department of Electrical Engineering, University of Sharjah, United Arab Emirates
}

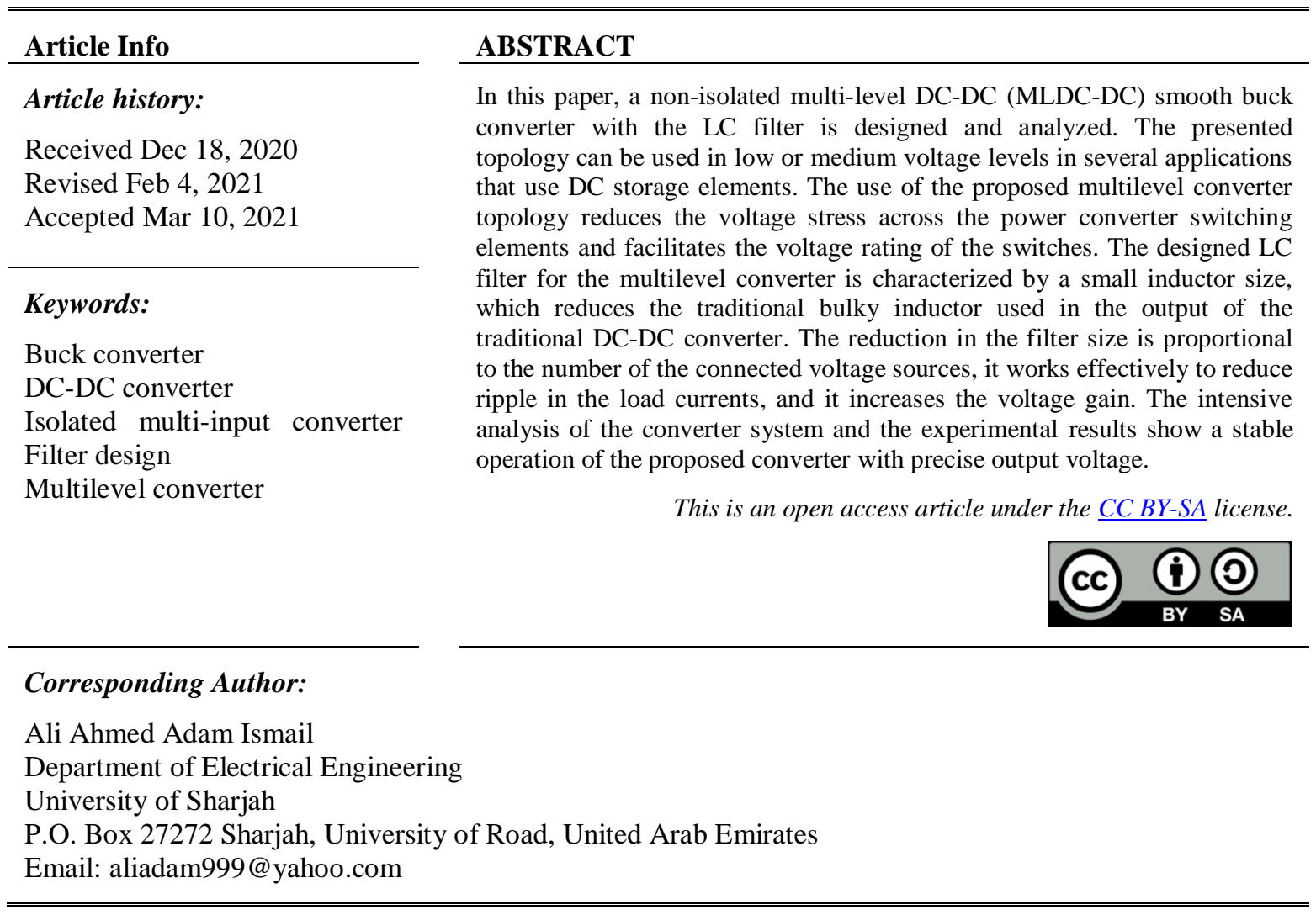

\section{INTRODUCTION}

In the last decades, there has been an increase in the renewable energy sources with DC output, which, can be utilized in many applications. However, since renewable energy sources are fluctuating, it is necessary to include storage devices in these systems. Storage systems based on batteries are a compact and flexible solution for many applications [1], [5] such as the photovoltaic power system, electrical propulsion drives for electric vehicles, electric trains, and electric ships. In such systems, designers connect batteries in series to increase the voltage level before connect them to the DC-DC power converter, which is adjusted for a certain required voltage level. A buck DC-DC converter can be used to control such high-level stabilized DC voltage of the batteries with high conversion efficiency. However, the hard voltage jumping during the switching operation increases the losses and generates switching harmonics at low- and high-frequencies. The propagation of the higher frequency signals in turn results in electromagnetic interference (EMI) emission through power converter elements. Therefore, some advanced control methods [6], [7] have been proposed using sliding mode control to deal with the problems. However, these methods fail to solve the problem of high switching ripples.

Beside buck converters, an arrangement of converters, which provides voltage multiplier [8], [9], are used to increase the DC output voltage in the cascaded boost mode. Several applications of cascaded boost converters are limited due to the disadvantages of high cost and bulky magnetic circuit that consumes major space of the converter. Furthermore, these types of converters normally require robust control of the boosted output voltage [9], which limits their effective utilization. Though its drawback mentioned above, the number 
of applications of the boost converter has recently increased due to its ability to handle high power values $[10,11]$.

The multilevel DC-DC converters with multi-inputs have been addressed widely [12]-[15] as a possible solution for handling the DC-DC power conversion with minimum possible ripples and harmonics. Broadly, the authors in [16] have divided these types of converters into two main groups; the first group is the isolated multi-level converters, which includes transformers to isolate the sources from the load, and the second one is the non-isolated multi-level converters, which have more simple structure and relatively simple control method.

In the type of the isolated multilevel converters, many authors have addressed the DC-DC conversion with different degree of success. For example, in [16] the authors present a configuration of isolated multi-input three-level DC-DC converter. The configuration has adopted high dc link voltage and integrated multiple dc sources to form three-level DC-DC converter before the isolation stage. Which, results in reduced components and allows flexibility in transformer design. The results of the converter in [16] shows excellent performance and stable operation of the converter. The authors in [13], [17] have proposed an isolated multilevel converter arrangement with many controlled switching elements, diodes, capacitors, LC filter and multi-winding transformer. Although the results in [13], [17] are satisfactory, the economic of its operation with many components at input or output power stages is questionable. In [18], an isolated fourchannel DC-DC converter has been proposed; the isolation is carried out with multi-output secondary winding transformer. The designed converter is used mainly as front-end of multiple inverter structures to integrate renewable energy sources with low voltage such as fuel cell stack, PV panels, and battery banks to micro grids. The configuration in [18] shows promising result for the application of multilevel inverters in smart grid system; however, the designed configuration utilizes many bulky components such as transformers, capacitors, and inductors.

The non-isolated multi-level DC-DC converters with its simple structure have been widely investigated in the literature. In [19]-[22] many configurations have been proposed with the multi-input system that can control the power of energy storage systems. To increase the output voltage in boost mode these configurations utilize inductors within the converter for each input source. Some of such configurations are used due to its advantage of decreasing cost and its high reliability of the control system [19]. Regarding their drawbacks, some topologies do not allow active power sharing between sources [20], and some others do not provide flexibility in terms of the switching and storage elements [21], [22]. In [23]-[25] different configuration types of non-isolated multi-level DC-DC converter have been designed. The authors in [23, 24] have directed their design to power flow control to realize high speed and high-precision power flow in a dc micro-grid; in addition, they have designed an LC output filter to suppress the switching current ripple. Although the current waveform shows good results for the design in [24], the number of the switching elements is relatively large which increases the cost of the converter. The DC-DC converter design in [25] provides capacitor voltage balancing and allows higher voltage utilization for the multilevel inverter. Although the design in [25] is directed to multilevel DC-DC buck converter, no multilevel output results are reported, which makes it difficult to evaluate the performance of the DC-DC converter. In general, the multilevel DC-DC converters can reduce the voltage jump in each switching operation, which results in decreasing the switching losses at low-frequency, and reduces the EMI [14]-[16]. In addition, it minimizes the size of the output filter that used to smooth the voltage [15].

In this paper, a multi-level DC-DC diode clamped non-isolated smooth converter is proposed. The suggested multilevel converter topology provides simple structure characterized by reduced number of switching elements, which is unlike the structure in [23], [24]. For n-level stable voltages, only n controllable switching elements and (n-1) clamped diodes are required. The paper as well; unlike the bulky filter required in [1]-[4], [8]-[11]; it proposes a relatively small size LC filter corresponding to the level of one voltage source. This suggested filter reduces the expensive bulky filter at the output of the traditional DC-DC converters. The paper as well, introduces novel intensive analysis of the converter that takes the leakage resistance and leakage inductance of the switching elements into consideration. We have validated the operation of the suggested converter experimentally. The obtained results show stable operation of the proposed converter with precise output voltage.

\section{RESEARCH METHOD}

Figure 1 shows the proposed circuit topology, it consists of the non-isolated DC-DC multilevel converter structured with clamped diodes [26], and a designed LC filter to smooth the output of the converter circuit. A control circuit measures the output voltage and compares it to the reference voltage in a closed loop structure to generate the appropriate switching signals to the converter circuit. The input to the proposed converter topology is composed of series connected battery-cell storage elements. Solar cell systems or 
similar renewable energy sources can energize these storage elements. The closed loop control circuit force the system to follow the reference output voltage irrespective of the variation of the cell voltages.

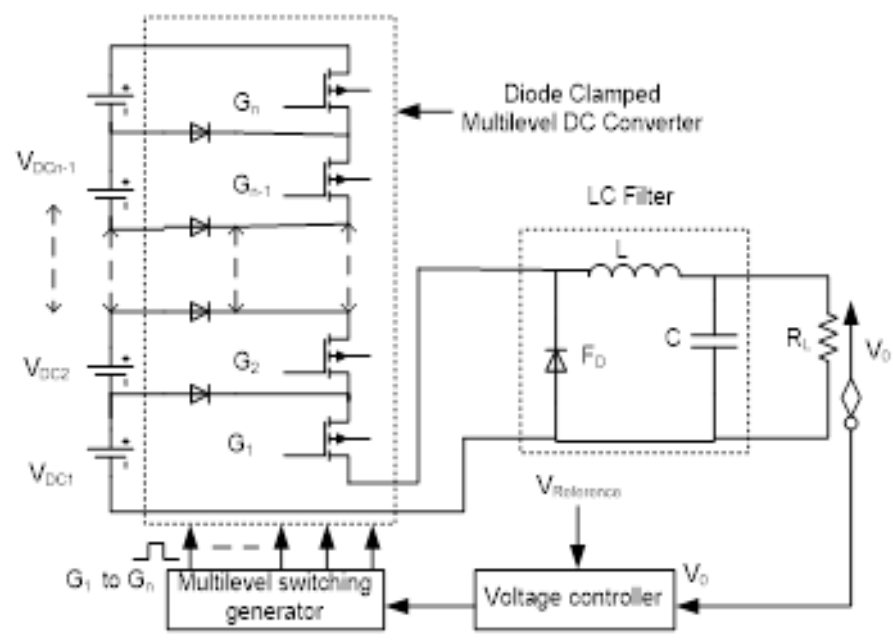

Figure1. Circuit topology of the proposed non-isolated multilevel DC-DC converter

The following sections give an intensive analysis of the proposed converter topology. It includes different modes of operations under different types of load with and without LC filter. The analysis as well shows the effect of using freewheeling diode with LC filter.

\subsection{Resistive load without filter}

Figure 2 (a) shows an approximated equivalent circuit for resistive load without output LC filter. In this figure, we represent the controlled switching elements with their ideal switching elements in series with internal resistance $r_{c h}$ and leakage inductance $L_{c h}$. The typical maximum values of these elements are $0.5 \Omega$ and $15 \mathrm{nH}$, respectively.

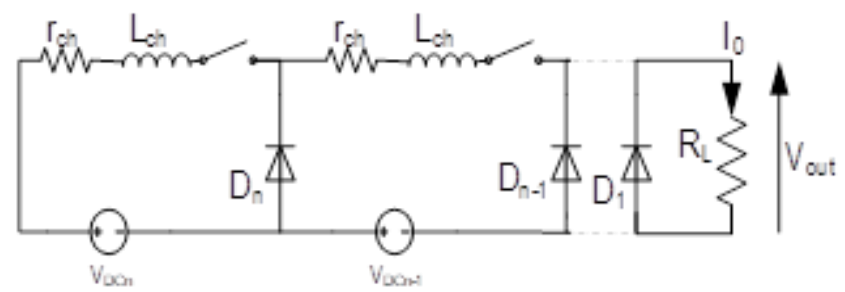

(a)

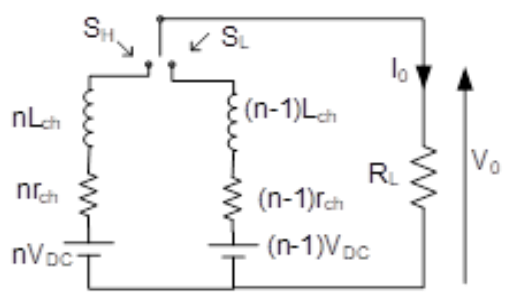

(b)

Figure 2. Electrical equivalent circuit of the non-isolated MLC with resistive load, (a) actual connection, (b) accumulated connection

Ignoring the values of $\mathrm{r}_{\mathrm{ch}}$ and $\mathrm{L}_{\mathrm{ch}}$, we can written the average output voltage across the load as,

$$
\left.\begin{array}{rl}
V_{\text {out }} & =\frac{T_{S} D n V_{D C}+T_{S}(1-D)(n-1) V_{D C}}{T_{S}} \\
& =n V_{D C}-(1-D) V_{D C} \quad \text { or } \\
& =(n-1) V_{D C}+D V_{D C}
\end{array}\right\}
$$

where, $\mathrm{D}$ is duty cycle that can be determined as described in [24], $\mathrm{D}=\left(\mathrm{V}_{\text {reference }}-\mathrm{V}_{\mathrm{n}-1}\right) /\left(\mathrm{V}_{\mathrm{n}}-\mathrm{V}_{\mathrm{n}-1}\right)$. So if $\mathrm{V}_{\mathrm{DC}}$ is $12 \mathrm{~V}$ for one cell unit, the required reference voltage is $28 \mathrm{~V}$, the output voltage is calculated as $2 * \mathrm{~V}_{\mathrm{DC}}+$ $\mathrm{DV}_{\mathrm{DC}}$, which is $(24 \mathrm{~V}+4 \mathrm{~V})$, with $\mathrm{D}=33.33 \%$. Consider the clamped diodes as ideal; we can write the output load current as, 


$$
I_{0}=\frac{V_{\text {out }}}{R_{L}}=\frac{(n-1) V_{D C}}{R_{L}}+\frac{D V_{D C}}{R_{L}}
$$

In (2), the term $\mathrm{DV}_{D C} / R L$ causes ripples and the current through the load is continuous. If we consider the inductances of the switching elements in the analysis, only one voltage source produces significant transient current and transient voltage variation in the output profile. Thus, we can write the system equations as follows:

During $\mathbf{n V D C} \boldsymbol{O N}$ mode: The switch SH connects the load to the $\mathrm{nV}$ _dcvoltage sources, thus we can express the voltage equation for the circuit in Figure 2 (b) as,

$$
n r_{c h} i_{0}+n L_{c h} \frac{d i_{0}}{d t}+v_{0}=n V_{D C}
$$

with pure resistive load, $v_{0}=R_{L} i_{0}$; and

$$
\left(n r_{c h}+R_{L}\right) i_{0}+n L_{c h} \frac{d i_{0}}{d t}=n V_{D C}
$$

The solution of the first order differential as shown in (4) is,

$$
i_{01}(t)=\frac{n V_{D C}}{R_{L}+n r_{c h}}+\left(I \frac{n V_{D C}}{R_{L}+n r_{c h}}-\frac{t}{n L_{c h} /\left(R_{L}+n r_{c h}\right)} s_{0 \text { min }}\right.
$$

where, $I_{O \min }$ is the initial inductor current during $\mathrm{nV}_{\mathrm{DC}}-\mathrm{ON}$ mode.

During (n-1) $\boldsymbol{V}_{\boldsymbol{D C}} \boldsymbol{O N}$ mode: The switch $\mathrm{S}_{\mathrm{L}}$ connects the load to the $(n-1) V_{D C}$ voltage source, and the corresponding load current is

$$
i_{02}(t)=\frac{(n-1) V_{D C}}{R_{L}+(n-1) r_{c h}}+\left(I \frac{(n-1) V_{D C}}{R_{L}+(n-1) r_{c h}}-\frac{t}{(n-1) L_{c h} /\left(R_{L}+(n-1) r_{c h}\right)} s_{S_{0 \max }}\right.
$$

The current components $I_{0 \max }$ and $I_{0 \min }$, shown in Figure 3, can be evaluated from (5) and (6) at time $D T_{s}$ and $T_{s}$ respectively as,

$$
\left.\left.I i_{02}\right|_{t=T_{s}} i_{01}\right|_{t=D T_{s} \max _{0 \min }}
$$

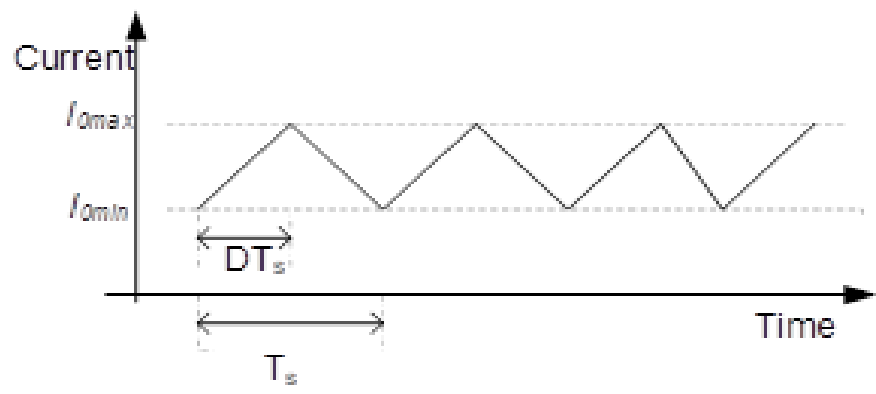

Figure 3. Current ripple in the MLC with resistive load

The ripple current is thereafter calculated as $\Delta I_{0}=I_{0 \max }-I_{0 \min }$. For switching frequency of $1 \mathrm{kHz}$, duty cycle of $50 \%$, and load resistance of $50 \Omega$ with typical values of $\mathrm{L}_{\mathrm{ch}}$ as $15 \mathrm{nH}$ and $\mathrm{r}_{\mathrm{ch}}$ as $0.5 \Omega$, the exponential time constant " $\tau$ " has a calculated value in the range of $\left[1.15 \times 10^{-9}-3 \times 10^{-10}\right]$ second, which is negligible for the transient current, and hence the load current components can be calculated directly as:

$$
i_{01}(t)=\frac{n V_{D C}}{R_{L}+n r_{c h}}, i_{02}(t)=\frac{(n-1) V_{D C}}{R_{L}+(n-1) r_{c h}}
$$

The ripple current is 


$$
\Delta I_{0}=\frac{n V_{D C}}{R_{L}+n r_{c h}}-\frac{(n-1) V_{D C}}{R_{L}+(n-1) r_{c h}} \simeq \frac{V_{D C}}{R_{L}+(2 n-1) r_{c h}}
$$

As shown (8) shows that the ripple current emanates due to change across one voltage cell only, which is smaller by a factor " $n$ " equal to the number of storage cells in series.

\subsection{Resistive load with $\mathrm{LC}$ filter}

To describe the operation of the proposed MLC with an LC filter, consider the simplified circuit shown in Figure 4.

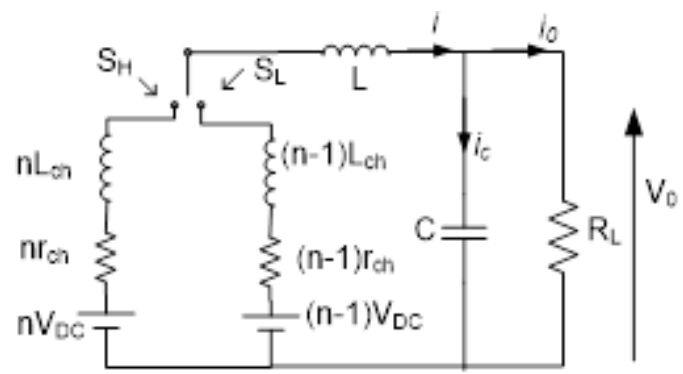

Figure 4. Accumulated equivalent circuit of MLC with LC filter

The inductance $\mathrm{L}$ of the filter is mostly in the range of $\mu \mathrm{H}$ or $\mathrm{mH}$, which permits the ignorance of the leakage inductance $\mathrm{nL}_{\mathrm{ch}}\left(60 \mathrm{nH}\right.$ for 4 levels) of the switching element. During $\boldsymbol{n} \boldsymbol{V}_{\boldsymbol{D C}} \boldsymbol{O N}$ mode $\left(\mathbf{0}<\mathbf{t}<\mathbf{D T} \mathbf{T}_{\mathrm{s}}\right)$ : The switch $\mathrm{S}_{\mathrm{H}}$ connects the load to the voltage source " $n V_{D C}$ ", so we can write the following equations:

$$
\left.\begin{array}{l}
i=i_{c}+i_{0} \\
v_{c}(t)=v_{0}(t) \\
n V_{D C}=L \frac{d i}{d t}+v_{01}(t)
\end{array}\right\}
$$

Assume linear variation of the inductor current, we can write:

$$
i_{L_{1}}(t)=\frac{n V_{D C}-v_{01}(t)}{L} t+I s_{L \min }
$$

During (n-1) $\boldsymbol{V}_{\boldsymbol{D C}} \boldsymbol{O N}$ mode $\left(\mathbf{D T}_{\mathrm{s}}<\mathrm{t}<\mathbf{T}_{\mathrm{s}}\right)$ : The inductor current is,

$$
i_{L_{2}}(t)=\frac{(n-1) V_{D C}-v_{02}(t)}{L}\left(t-D T_{s}\right)+I_{L \max } ; D T_{s}<t<T_{s}
$$

Where

$$
\begin{aligned}
I L \mid t & =D T_{S_{L \max }} \\
& =\frac{n V_{D C^{-} v_{01}\left(D T_{S}\right)}}{L} D T_{S}+I_{L m i n}
\end{aligned}
$$

The average value of the output voltage and output currents are:

$$
V_{0}=\frac{1}{T_{S}}\left[\int_{0}^{D T_{S}} v_{01}(t) d t+\int_{D T_{S}}^{T_{S}} v_{02}(t) d t\right]=(n-1) V_{D C}+D V_{D C}
$$




$$
I_{0}=\frac{(n-1) V_{D C}+D V_{D C}}{R}
$$

We can approximate the average current ripple where $f$ is the sampling frequency. in the inductor as,

$$
\left.\begin{array}{rl}
\Delta I_{L} & =I_{L \max }-I_{L \min } \\
& =\frac{n V_{D C}-\left[(n-1) V_{D C}+D V_{D C}\right]}{L} D T_{s} \\
& =\frac{V_{D C}-D V_{D C}}{L} D T_{s}=\frac{V_{D C}(1-D) D}{f L}
\end{array}\right\}
$$

The above equation shows clearly that the current ripple is due to one voltage source only out of $n$ connected voltage sources, which is the similar to the result deduced in (8). The capacitor current $i_{c}$ flows due to alternating component of the output voltage as,

$$
i_{c}(t)=c \frac{d v_{c}(t)}{d t}=c \frac{d v_{0}(t)}{d t}
$$

Bearing in the mind the shape of the inductor current along with the shape of ripple in the output current, the variation in the capacitor voltage takes the shape of the waveform as given in Figure 5 [27]. Hence, we can approximate the variation of the capacitor voltage as:

$$
\left|\Delta v_{c}\right|=\frac{\Delta i_{0}}{8 C f}=\frac{V_{D C}(1-D) D}{8 L C f^{2}}
$$

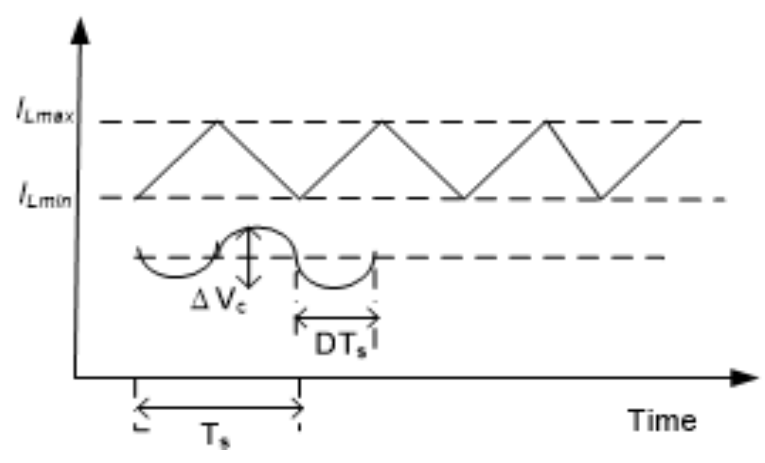

Figure 5. Approximation of capacitor voltage

To design a suitable LC filter to smoothen the output voltage and current, we can select the capacitor and inductor values according to equation (15) and (17). Assume a maximum of $4 \%$ current ripple and $2 \%$ of voltage ripple; we can calculate the filter values with $50 \%$ duty cycle as in Table 1.

Table 1. Filter parameter values at different switching frequency

\begin{tabular}{ccc}
\hline Variable & Values at $1 \mathrm{kHz}$ & Values at $10 \mathrm{kHz}$ \\
\hline $\mathrm{L}$ & $15 \mathrm{mH}$ & $1.5 \mathrm{mH}$ \\
$\mathrm{C}$ & $25 \mu \mathrm{F}$ & $2.5 \mu \mathrm{F}$ \\
Cell voltage & $12 \mathrm{~V}$ & $12 \mathrm{~V}$ \\
Load current & $5 \mathrm{~A}$ & $5 \mathrm{~A}$ \\
Number of cells & 4 & 4 \\
\hline
\end{tabular}

\subsection{LC filter operation with freewheeling diode}

Consider the shown LC filter attached to the MLC with freewheeling diode in Figure 6. We can describe the operation of the MLC in this case by the following equations: 


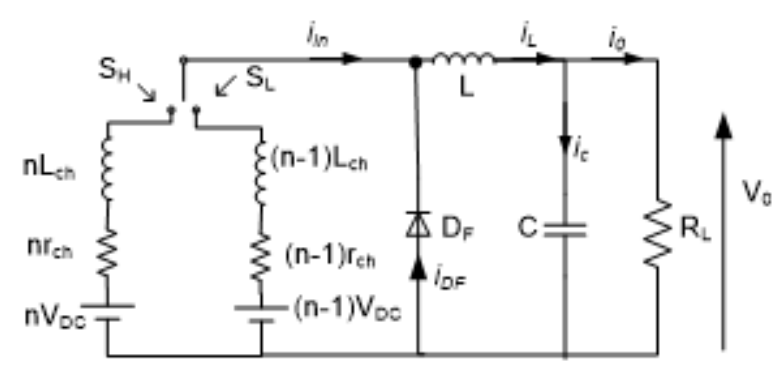

Figure 6. Equivalent circuit of MLC with LC filter and freewheeling diode

During the $\boldsymbol{n} \boldsymbol{V}_{\boldsymbol{D C}} \boldsymbol{O N}$ mode: The freewheeling is in reverse biasing condition. Ignore the switching elements leakage inductance and resistance, we can write the system equations as,

$$
\left.\begin{array}{l}
n V_{D C}=v_{L}+v_{c}=L \frac{d i_{L}}{d t}+v_{c} \\
v_{0}=v_{c}=R_{L} i_{0} \\
i_{\text {in }}=i_{L}=i_{0}+i_{c}
\end{array}\right\}
$$

Assume constant output voltage during $D T_{s}$ due to capacitor effect, we can write the inductor current $i_{L H i g h}$ as,

$$
i_{L-H i g h}=\frac{n V_{D C}-v_{0}(t)}{L} t+I_{L m i n}
$$

As shown in (19) is the same as (10). During the Freewheeling mode: The freewheeling diode takes the role by passing the stored energy in the inductor to the load. During this mode, we can write the system equations as,

$$
\left.\begin{array}{l}
v_{D F}=0 ; \quad i_{\text {in }}=0 ; \quad i_{L}=i_{0}-i_{c}=i_{D F} \\
v_{0}(t)=-v_{L}(t)=-L \frac{d i_{L}}{d t} \text { or } \\
i_{L}=-\frac{v_{0}(t)}{L}\left(t-D T_{S}\right)+I_{L \max } \\
\left.I i_{L-H i g h}\right|_{t=D T_{S \max }}
\end{array}\right\}
$$

In (20) as the voltage source is disconnected, the capacitor discharges and changes current direction, hence the inductor current decreases. During the $(\mathbf{n}-\mathbf{1}) \mathbf{V}_{\mathbf{D C}} \mathbf{O N}$ mode: The switch is connected to the lower voltage level of $(n-1) V_{D C}$ volt. The system equation can be written as,

$$
\left.\begin{array}{l}
(n-1) V_{D C}=v_{L}+v_{C}=L \frac{d i_{L}}{d t}+v_{C} \\
\text { with possible solution: } \\
i_{L-\text { Low }}=\frac{(n-1) V_{D C}-v_{0}(t)}{L} t+I_{L \max }^{\prime}
\end{array}\right\}
$$

where $I_{\text {Lmax }}^{\prime}$ is evaluated from (20) asi $\left.i_{L}\right|_{t=t^{\prime}+D T_{S}}$; with $t^{\prime}$ is the switching ON time of the switching element. Excluding the transition effect of the switch time " $t$ '", we can express the average output voltage as,

$$
\left.\begin{array}{rl}
V_{0} & =\frac{1}{T_{s}}\left[\int_{0}^{D T_{s}} v_{0}(t) d t+\int_{D T_{s}}^{T_{s}} v_{0}(t) d t\right] \\
& =\frac{1}{T_{s}}\left[\int_{0}^{D T_{s}}\left(n V_{D C}-L \frac{d i_{L}}{d t}\right) d t+\int_{D T_{s}}^{T_{s}}\left((n-1) V_{D C}-L \frac{d i_{L}}{d t}\right) d t\right] \\
& =\frac{1}{T_{s}}\left[n V_{D C} D T_{s}+(n-1) V_{D C}(1-D) T_{s}\right]-\frac{L}{T_{s}}\left[\left.\Delta i^{+}\right|_{0} ^{D T_{s}}+\left.\Delta i^{-}\right|_{D T_{s}} ^{T_{s}}\right]
\end{array}\right\}
$$


where $\Delta i^{+}$and $\Delta i^{-}$in this case represent the increment and decrement of the inductor current during $\left(0-D T_{s}\right)$ and $\left(D T_{s}-T_{s}\right)$, respectively. For $50 \%$ duty cycle, these components $\left(\Delta i^{+}\right.$and $\left.\Delta i{ }^{-}\right)$are added to be very small (can be ignored). Therefore, with the proper selection of the inductance $L$, we can keep the voltage ripple minimum and fairly estimate the output voltage $\mathrm{V}_{0}$ as,

$$
V_{0}=(n-1) V_{D C}+D V_{D C}
$$

According to the above equation, when the system operates at definite voltage level ( $n$ is constant), the maximum dynamic variation in output voltage will be caused by only one voltage cell of $V_{D C}$. Which, results in smaller filter components by a factor of $\mathrm{n}$ if compared with the traditional single switch chopper circuit.

\section{RESULTS AND DISCUSSION}

The experimental setup shown in Figure 7 is composed of 4-level DC-DC converter arrangement built with 4 power MOSFET and 3 fast switching clamped diodes. The load is composed of pure resistive load. The designed LC filter parameters corresponding to creteria as shown in (15), (16), load, and battery cells, information are given in Table 2. The design creteria for the LC filt is based on selected

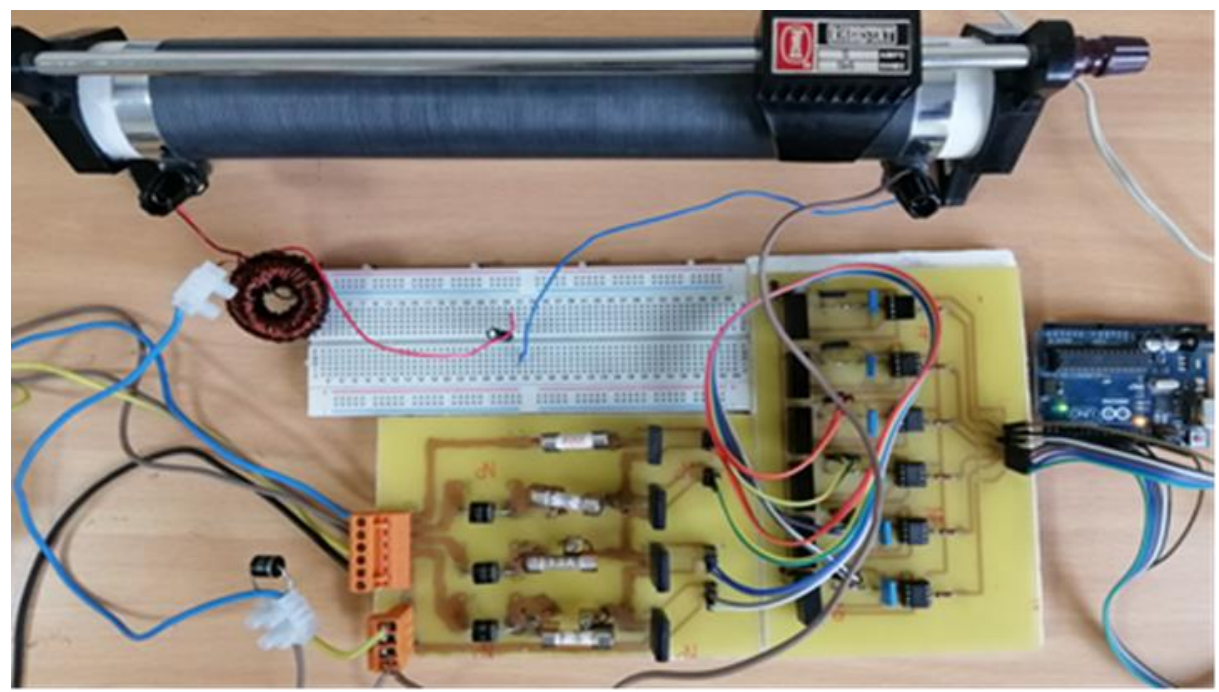

Figure 7. Experimental setup of multilevel DC-DC converter

Table 2. Setting of the parameters used in the experiment.

\begin{tabular}{ccc}
\hline Variable & Value & Type \\
\hline Switching frequency & $10 \mathrm{kHz}$ & \\
$\mathrm{L}$ & $0.6 \mathrm{mH}$ & \\
$\mathrm{C}$ & $2.0 \mu \mathrm{F}$ & \\
$\mathrm{R}$ & $0-50 \mathrm{Ohm}$ & \\
Cell voltage & 4 cells each of 12V & Solar, RAYTON 12V, 100AH \\
Load current & $0-5 \mathrm{~A}$ & \\
Diodes & 4 & Fast recovery diode, P600k \\
Controllable switching elements & 4 & MOSFET, IRFP460 \\
\hline
\end{tabular}

Figure 8 shows the output voltage without filter. The applied input reference voltage continuously repeats with level of $6 \mathrm{~V}, 42 \mathrm{~V}$, and $18 \mathrm{~V}$, the duration of each level is 1 second. The output waveform shows that the output voltage keeps switching between two consecutive voltage levels, which limit the magnitude of the ripple in the output voltage to the maximum of one cell voltage level. For example, when the required voltage level is 42 volt, the output waveform oscillate between 48 and 36 volt only which results in maximum of 12-volt ripple for resistive load without filter. If we use hard switching in traditional chopper, the output voltage will oscillate between 0 and 48 volt, which increases the ripple to 48 volt. Figure. 9 shows 
the simulated results of comparison of the output voltages of the traditional hard switching chopper and the proposed method. This result is in correspondence with the results as shown in (8) and (13).

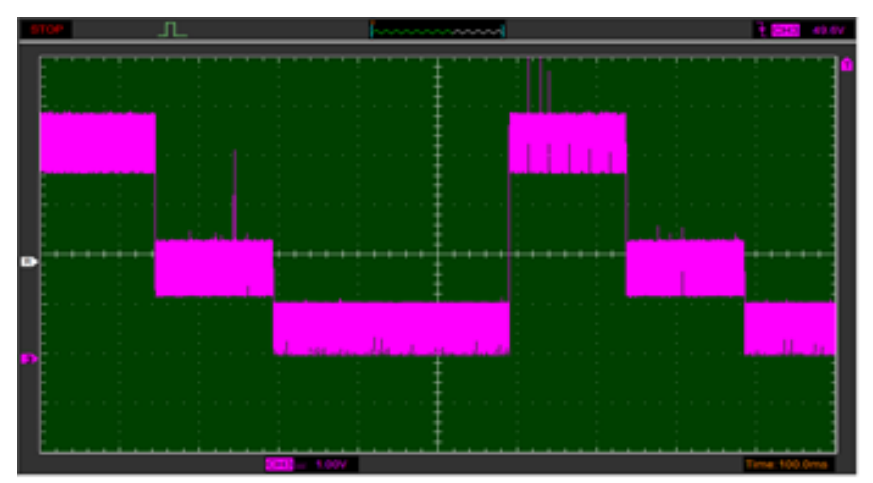

Figure 8. Input voltage pattern $(42 \mathrm{~V}-18 \mathrm{~V}-6 \mathrm{~V})$ at no load without filter

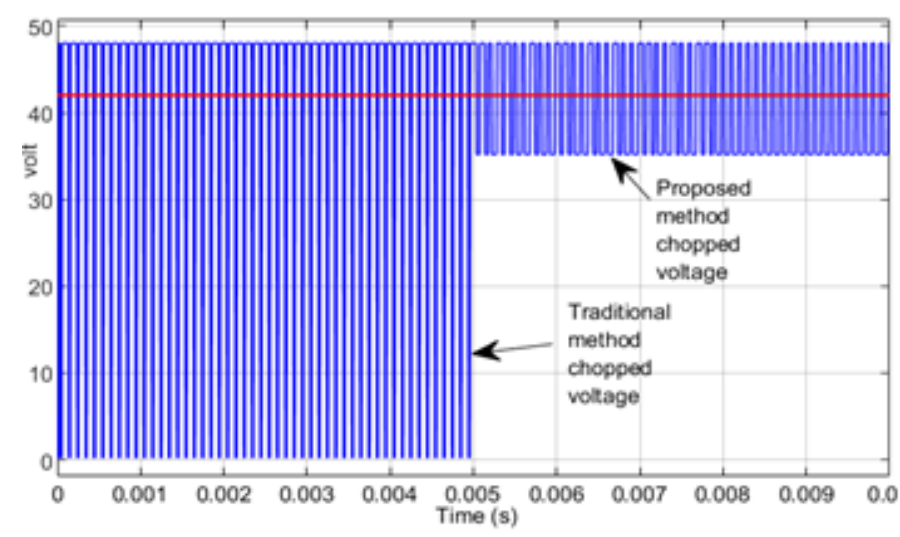

Figure 9. Simulated results of voltage ripples of the proposed method compared to tradition method to obtain 42-volt reference voltage

To demonstrate the effectiveness of the designed MLC towards filter design, we subject the output voltage to relatively smaller LC filter with parameters as given in Table 2 . With the system connections as given in Figure 4, the output voltage waveform is smoothened as shown in Figure 10 with relatively large resistive load. However, with load resistance of $50 \Omega$, we have obtained acceptable filtered waveform as in Figure11. The effect of the designed LC filter and how it affects positively the ripple in the input waveform can be confirmed by comparing the input voltage at the input of the inductor and the output voltage at the terminals of the load as shown in Figures 10 and 11. The approximate measured ripple voltages in Figure 11 are $0.8 \mathrm{~V}, 1$ volt and $1.6 \mathrm{~V}$ for the reference voltages of 6,18 and $42 \mathrm{~V}$ respectively.

The effect of the freewheeling diode in the operation of the proposed converter is tested with the connection shown in Figure 6 along with the parameters shown in Table II. The obtained results of the input current, the load current, capacitor current, and freewheeling current are displayed in Figure12. Comparing the input current in Figure 12 (a) with the load current waveform in Figure12 (b) shows clearly the role of the LC filter in smoothing the load current. Most of the current ripples pass to the ground through the shunt capacitor of the filter as documented in Figure 12 (c). Figure 12 (d) shows the effect of the freewheeling diode in the filtering operation. The freewheeling diode in the system remains idle for all voltage levels except when the required output voltage is less than the voltage of one-unit cell (12 volts in this experiment). We can observe this effect clearly in the magnified diode current in Figure13, where the freewheeling diode current remains inactive except for the transient switching time " $t$ ". The transient switching time as well affects the smooth charging and discharging operation as shown in the magnified capacitor current in Figure 13. 


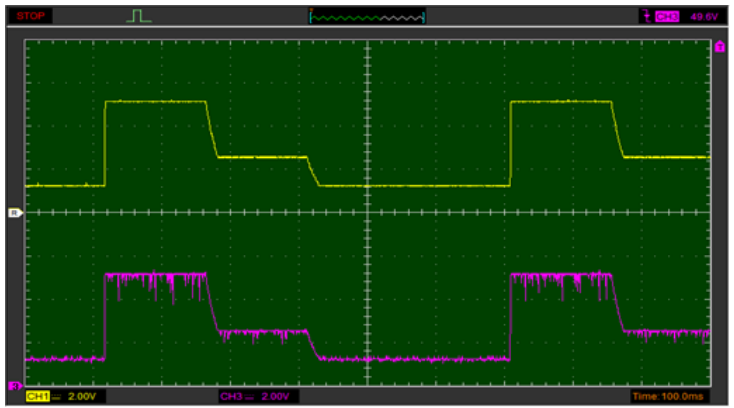

Figure 10. Filtered capacitor terminals voltage pattern (upper-yellow) and input

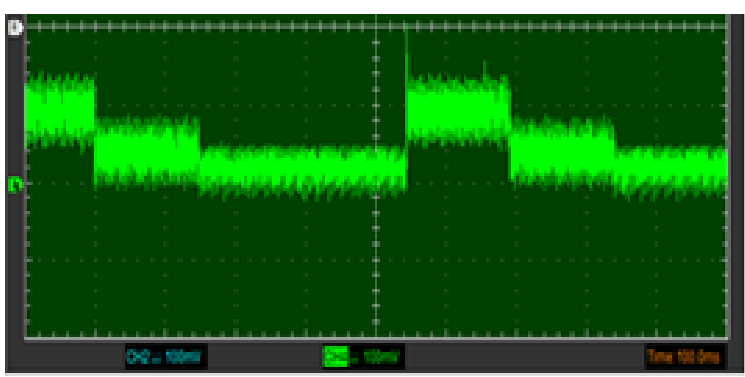

(a)

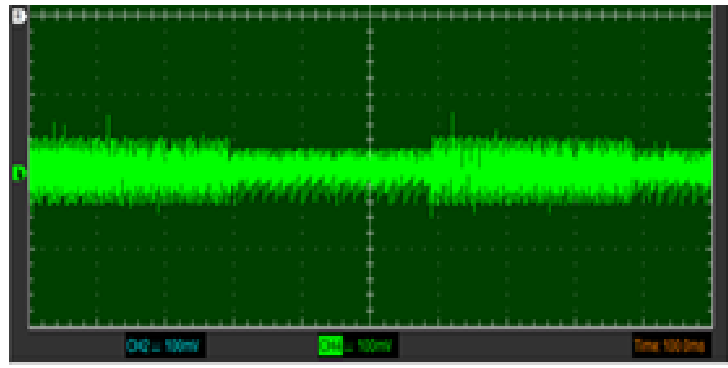

(c)

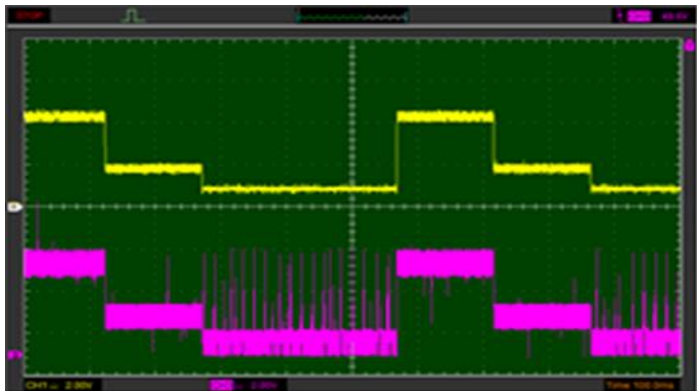

Figure 11. Filtered Load voltage (upper-yellow) at capacitor terminals and input voltage (Lower-Pink) at inductor inputs, with $50 \mathrm{Ohm}$ load. Scale 20volt/division

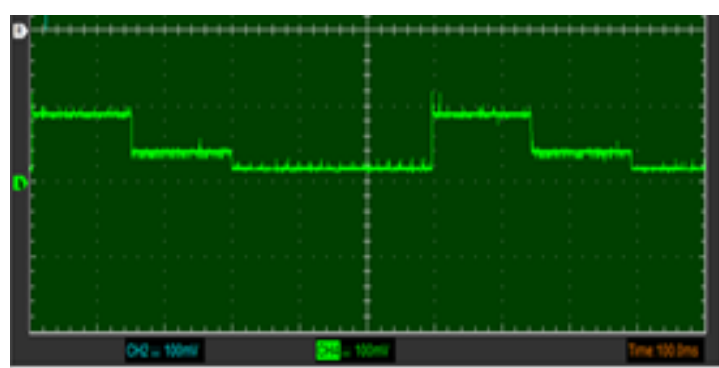

(b)

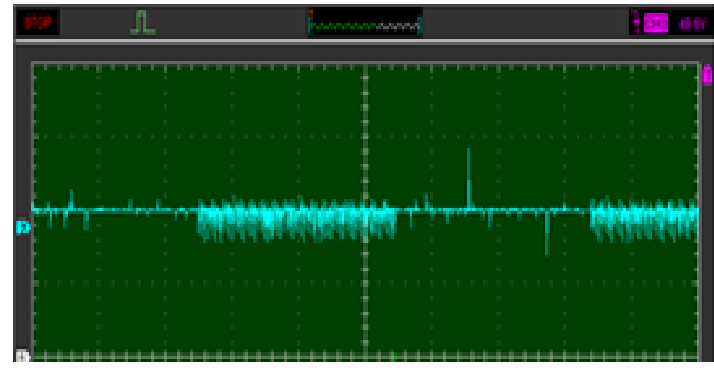

(d)

Figure 12. (a) Input current to the inductor, (b) Output load current, (c) Capacitor current (d) Freewheeling currents. Scale: 1 A/division

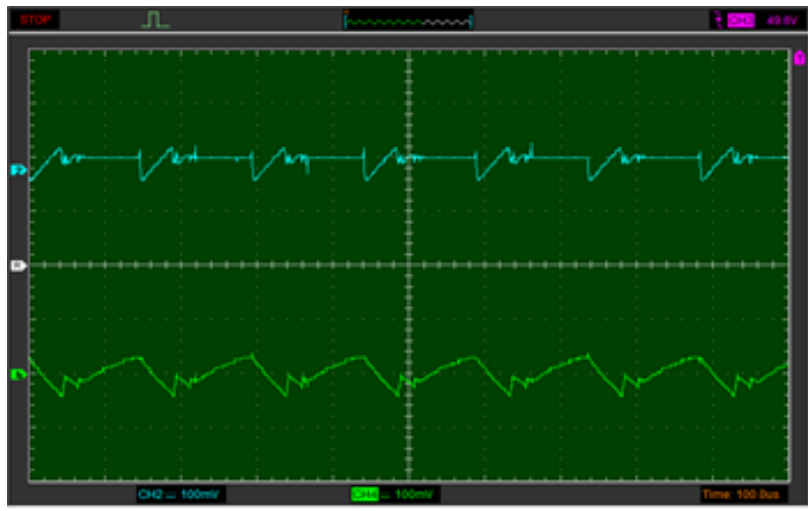

Figure 13. Freewheeling diode currents (upper-blue) and capacitor currents (lower-green) 


\section{CONCLUSION}

In this paper, a non-isolated multi-level DC-DC smooth buck converter with output LC filter has been proposed and analyzed. The use of proposed multilevel converter topology reduces the voltage stress across the power converter switching elements (power MOSFET) and improves the voltage rating of the switching elements. The analysis of the proposed topology includes the effect of the leakage inductances and resistances of the switching elements. The analysis shows that with the proposed topology only one voltage source produces significant transient voltage variation in the output profile during the variation of the input reference voltage. Hence, the ripple currents in the output emanates mainly due to change across one voltage cell only. Which is smaller by a factor " $n$ " equal to the number of the batteries connected in series. The comparison results of the output waveform of the proposed topology and the output waveform of the traditional hard switching chopper shows the improvements and the advantages of this proposed method. In order to reduce ripple in the load currents and improve the voltage stability, the paper introduces detailed design of a relatively small size LC filter to be used at the output of the converter. The analysis of the designed filter shows that we can minimize the LC filter requirements by a factor equal to the number of the connected voltage sources. The intensive analysis and the experimental results show stable operation with a precise output voltage of the proposed converter either with or without the LC filter. The results show that the effect of the freewheeling diode is limited to the case when the required output voltage is less than the voltage of one unit cell of the source voltage ( $12 \mathrm{~V}$ in this experiment).

\section{REFERENCES}

[1] P. Vipin Das, A. K. Singh, K. Pi, B. Babu, "Modelling, simulation and analysis of high step-up DC-DC converter using coupled inductor and voltage multiplier cell using PSCAD," International Journal of Modelling and Simulation, vol. 40, no.1, pp. 1-8, DOI:10.1080/02286203.2018.1517494.

[2] R. Carnegie, T. Buehler, D. Chartouni, "Utility scale energy storage systems - benefits, applications and technologies," Technical report, US - State Utility Forecasting Group, Nov. 2013, DOI: 10.1109/ENERGY.2008.4780999.

[3] A. A. Freitas, E. Mineiro, F. Tofoli, "Analysis of high voltage step-up non isolated DC-DC boost converters," International Journal of Electronics, vol. 103, no. 5, pp 898-912, May 2016, DOI: 10.1080/00207217.2015.1077529.

[4] T. Nouri, et al., "Interleaved high step-up dc-dc converter based on three-winding high frequency coupled inductor and voltage multiplier cell," IET Power Electronics, vol. 8, no. 2, pp 175-189, Feb. 2015, DOI: 10.1049/ietpel.2014.0165.

[5] M. Khalilzadeh, and K. Abbaszadeh, "Non-isolated high step-up DC-DC converter based on coupled inductor with reduced voltage stress," IET Power Electronics, vol. 8, pp 2184-2194, 2015.

[6] K. B. Siddesh, et al., "Enhanced sliding mode controller performance in DC-DC buck converter using a tan hyperbolic reaching law and constant plus proportional reaching law", Bulletin of Electrical Engineering and Informatics, vol. 9, no. 2, pp. 525-532, Apr. 2020, DOI: 10.11591/eei.v9i2.2100.

[7] K. B. Siddesh, et al.," Comparison analysis of chattering in smooth sliding mode controlled DC-DC buck converter using constant plus proportional reaching law and proposed reaching laws", Bulletin of Electrical Engineering and Informatics, vol. 9, no. 3, pp. 1291-1298, Jun. 2020, DOI: 10.11591/eei.v9i3.1780.

[8] S Padhee, et al., "Overview of high step-up DC-DC converters for renewable energy sources," IETE Tech Rev, vol. 35, pp. 1-7, 2016.

[9] Said Oucheriah, "Robust control of the DC-DC boost converter based on the uncertainty and disturbance estimator", International Journal of Electronics, vol. 104, no. 11, pp. 1810-1822, May 2017.

[10] T. M Aiswarya, M. Prabhakar, "An efficient high gain DC-DC converter for automotive applications," International Journal of Power Electronics and Drive System (IJPEDS), vol. 6, no. 2, pp. 242-252, Jun. 2015, DOI: 10.11591/ijpeds.v6.i2.pp242-252.

[11] R. Girish Ganesan, and M. Prabhakar, "Multi-level DC-DC converter for high gain applications," International Journal of Power Electronics and Drive System (IJPEDS), vol. 3, no. 4, pp. 365-373, Dec. 2013, DOI: 10.11591/ijpeds.v4i1.4870.

[12] B. M. Manjunatha, V. Kumar, A.Kumar, "A simplified PWM technique for isolated DC-DC converter fed switched capacitor multi-level inverter for distributed generation," International Journal of Power Electronics and Drive System (IJPEDS), vol. 8, no. 3, pp. 1230-1239, Sep. 2017, DOI: 10.11591/ijpeds.v8.i3.pp1230-1239.

[13] K. Filsoof and P. W. Lehn, "Design and control of a bidirectional triangular modular multilevel DC-DC converter," Proc. IEEE 14th Workshop Control Model. Power Electron, Jun. 2013, DOI: 10.1109/COMPEL.2013.6626434.

[14] Z. Pan, F. Zhang, F. Z. Peng, "Power losses and efficiency analysis of multilevel dc-dc converters," Proc. IEEE 20th Апnи. Appl. Power Electron. Conf. Expo., vol. 3, pp. 1393-1398, Mar. 2005, DOI: 10.1109/APEC.2005.1453209.

[15] F. Zhang, F. Z. Peng, Z. Qian, "Study of multilevel converter in DC-DC applications," Proc. IEEE 35th Annual Power Electronics. Spec. Conference, Jun. 2004, pp. 1702-1706, DOI: 10.1109/PESC.2004.1355682. 
[16] S. Dusmez, X. Li, B. Akin, "A new multiinput three-level DC/DC converter," IEEE Transaction on Power Electronics, vol. 31, no. 2, pp 1230-1240, Feb. 2016, DOI: 10.1109/TPEL.2015.2424246.

[17] Hurng-Liahng Jou, et al., "Novel isolated multilevel DC-DC power converter," IEEE Transaction on Power Electronics, vol. 31, no. 4, pp2690-2694, Apr. 2016, DOI: 10.1109/TPEL.2015.2487558.

[18] S. Sathyan, et al., "Soft-switched interleaved DC/DC converter as front-end of multi-inverter structure for micro grid applications," IEEE Transaction on Power Electronics, vol. 33, no. 9, pp. 7645-7655, Sept. 2018, DOI: 10.1109/TPEL.2017.2768379.

[19] F. Akar, et al., "A bidirectional non-isolated multi-input DC-DC converter for hybrid energy storage systems in electric vehicles," IEEE Transactions on Vechicular Technology, vol. 65, no. 10, pp. 7944-7955, Oct. 2016, DOI: 10.1109/TVT.2015.2500683.

[20] F. Nejabatkhah, et al., "Modeling and control of a new three-input dc-dc boost converter for hybrid PV/FC/battery power system," IEEE Transaction Power Electronics, vol. 27, no. 5, pp. 2309-2324, May 2012, DOI: 10.1109/TPEL.2011.2172465.

[21] A. Khaligh, et al., "A multiple-input DC-DC converter topology," IEEE Transaction Power Electronics, vol. 24, no. 3, pp. 862-868, Mar. 2009, DOI: 10.1109/LPEL.2003.813481.

[22] S. Danyali, S. Hossein, G. B. Gharehpetian, "New extendable single-stage multi-input DC-DC/AC boost converter," IEEE Transaction Power Electronics., vol. 29, no. 2, pp. 775-788, Feb. 2014, DOI: 10.1109/TPEL.2013.2256468.

[23] J. Gregory Kish, "On the emerging class of non-isolated modular multilevel DC-DC converters for DC and hybrid AC-DC systems," IEEE Transaction on Smart Grid, vol. 10, no. 2, pp. 1762-1771, Mar. 2019, DOI: 10.1109/TPEL.2013.2256468.

[24] M. Katayama, et al., "Application of multi-level converter for fast current control in small-scale DC power network," IEEE Transactions on Industry Applications, vol. 55, no. 3, pp. 2902-2909, May 2019, DOI: 10.1109/TIA.2019.2896839.

[25] A. Keith Corzine, et al., "Analysis of a four-level DC/DC buck converter," IEEE Transactions on Industrial Electronics, vol. 49, no. 4, Aug. 2002, DOI: 10.1109/IAS.2001.955787.

[26] A. A. Adam, and A. Elnady, "Advanced drive system for DC motor using multilevel DC/DC buck converter circuit," IEEE Access, Apr. 2019, DOI: 10.1109/ACCESS.2019.2912315.

[27] H. Rashid, "Power electronics: circuits, devices, and applications," Fourth Edition, Prentice Hall, 2014. 